\title{
GABAergic Transmission to Gonadotropin-Releasing Hormone (GnRH) Neurons Is Regulated by GnRH in a Concentration-Dependent Manner Engaging Multiple Signaling Pathways
}

\author{
Peilin Chen ${ }^{1}$ and Suzanne M. Moenter ${ }^{1,2}$ \\ Departments of ${ }^{1}$ Medicine and ${ }^{2}$ Cell Biology, University of Virginia, Charlottesville, Virginia 22908
}

Gonadotropin-releasing hormone (GnRH) neurons are the central regulators of fertility. GnRH stimulates or inhibits GnRH neuronal activity depending on dose. The mechanisms for these actions remain unknown. We hypothesized GnRH acts in part by altering fast synaptic transmission to GnRH neurons. GABAergic and glutamatergic postsynaptic currents (PSCs), both of which can excite these neurons, were recorded from GnRH neurons in brain slices from adult intact and orchidectomized (ORX) males. ORX enhanced the frequency of GABA transmission to GnRH neurons, but had no effect on glutamatergic transmission. Effects of ORX on GABAergic transmission were reversed by estradiol replacement, suggesting GABA is a mediator of steroid feedback in males. GABAergic neurons express type-1 GnRH receptor (GnRHR-1). Low GnRH $(20 \mathrm{nM})$ reduced GABAergic PSC frequency in GnRH neurons from both ORX and intact mice. High GnRH $(2 \mu \mathrm{M})$ had no effect on either GABAergic or glutamatergic transmission to GnRH neurons. To investigate mechanisms mediating low-dose GnRH suppression of GABAergic transmission, GABAergic PSCs were recorded after arresting $G_{\alpha i}$ activity with pertussis toxin (PTX). PTX abolished the suppressive effect of low GnRH. Moreover, PTX uncovered a stimulatory effect of high GnRH on GABAergic transmission. These data suggest low-dose GnRH suppresses GnRH firing rate in part by decreasing GABAergic transmission to the GnRH neurons, independent of gonadal hormone milieu. Low-dose GnRH appears to exert the suppressive effect by activating GnRHR-I coupled to $\mathrm{G}_{\alpha \mathrm{i}}$. The concentration-dependent effects of $\mathrm{GnRH}$ may be mediated in part by changes in affinity of $\mathrm{GnRH}$ to GnRHR-I coupled to different $\mathrm{G}_{\alpha}$ proteins.

\section{Introduction}

Gonadotropin-releasing hormone ( $\mathrm{GnRH}$ ) neurons form the final common pathway for the central regulation of fertility. GnRH is released in distinct pulses, which are essential for reproduction (Belchetz et al., 1978; Levine and Ramirez, 1982; Moenter et al., 1992). Pulsatile GnRH output likely requires coordination among individual GnRH neurons, which are few in number and scattered (Silverman, 1994). This anatomical arrangement suggests the existence of a local network that facilitates communication among GnRH neurons. Substantial evidence indicates GnRH itself may serve as a part of this network. GnRH neurons form axodendritic and axosomatic synapses on one another (Witkin and Silverman, 1985), express the type $1 \mathrm{GnRH}$ receptor GnRHR-1, and respond to GnRH (Xu et al., 2004; Todman et al., 2005). In mouse brain slices from females, GnRH increased GnRH neural activity (Todman et al., 2005); in contrast, in cas-

Received May 29, 2009; revised June 18, 2009; accepted July 1, 2009.

This work was supported by National Institutes of Health Grants HD34860, T32HD07382, and F32HD056765 to P.C. We thank Debra Fisher for excellent technical assistance, Chien Li for providing reagents and equipment for histology work, and Pei-San Tsai for editorial comments.

Correspondence should be addressed to Suzanne M. Moenter, Departments of Medicine and Cell Biology, University of Virginia, Charlottesville, VA 22908. E-mail: Moenter@virginia.edu.

DOI:10.1523/JNEUROSCI.2509-09.2009

Copyright $\odot 2009$ Society for Neuroscience $\quad$ 0270-6474/09/299809-10\$15.00/0 trate males low doses of GnRH inhibited firing activity, whereas high doses stimulated firing activity (Xu et al., 2004).

The mechanisms by which GnRH modulates GnRH neuronal activity in a concentration-dependent manner are not known. One possible mechanism for this is via interactions with local networks. Unidentified non-GnRH neurons in the preoptic area express GnRHR-1 (Xu et al., 2004; Todman et al., 2005). GABAergic neurons provide a major synaptic input to GnRH neurons (Leranth et al., 1985; Sim et al., 2000; Jansen et al., 2003) that is modified by physiological conditions (Sullivan et al., 2003; Christian and Moenter, 2007) and could serve as an intermediary to transmit $\mathrm{GnRH}$ signals to other $\mathrm{GnRH}$ neurons. $\mathrm{GABA}_{\mathrm{A}} \mathrm{R}$ activation can inhibit or excite a cell depending on intracellular chloride levels (Kaila, 1994; Rivera et al., 1999) and membrane potential. Adult GnRH neurons maintain high intracellular chloride and can be depolarized and excited by GABA (DeFazio et al., 2002; Yin et al., 2008). GnRH neurons also receive glutamatergic input (Suter, 2004) that is modified by steroid milieu (Christian et al., 2009).

GnRHR-1 is the sole cognate receptor for GnRH in the mouse (Millar, 2003) and can couple to and regulate multiple $G$ proteins (Hsieh and Martin, 1992; Hawes et al., 1993). Studies of immortalized GnRH neurons showed that GnRH signals via different postreceptor signaling mechanisms depending on ligand concen- 
tration (Krsmanovic et al., 2003). Together, these data suggest the hypothesis that concentration-dependent responses to $\mathrm{GnRH}$ engage at least two signaling pathways during activation of GnRHR-I (López de Maturana et al., 2008; Millar et al., 2008).

Here, we investigate the relationship of $\mathrm{GnRH}$ dose and changes in GABA and glutamate transmission to GnRH neurons. We tested the hypotheses that low-dose GnRH suppresses, whereas high dose increases fast synaptic transmission to $\mathrm{GnRH}$ neurons. To test whether low and high doses of $\mathrm{GnRH}$ couple to different $G$ proteins, we used $G_{\alpha \mathrm{i}}$ inhibitor pertussis toxin (PTX) to eliminate possible $\mathrm{G}_{\alpha \mathrm{i}}$ signaling activated by $\mathrm{GnRH}$. Our findings indicate $\mathrm{GnRH}$ may alter GnRH neuronal activity by modulating activity of GABAergic afferents, and that high and low GnRH engage different postreceptor signaling pathways resulting in different cellular responses.

Portions of this work were presented in abstract form at the 2007 Society for Neuroscience Meeting (Chen and Moenter, 2007) and 2009 Endocrine Society Meeting (Chen and Moenter, 2009).

\section{Materials and Methods}

Animals. Adult (42-120 d) transgenic male mice in which green fluorescent protein (GFP) is genetically targeted to GnRH neurons were used for all studies (Suter et al., 2000). Mice were housed on a $14 \mathrm{~h}$ light, $10 \mathrm{~h}$ dark cycle, with lights off at 4:30 P.M., and were maintained on Harlan 2916 rodent chow (Harlan) and water ad libitum. Mice were orchidectomized (ORX) under isoflurane (Abbott Laboratories) anesthesia 5-9 d before recordings to avoid confounds of gonadal feedback and of long-term removal of steroids. A group of ORX mice received estradiol (E) implants $(\mathrm{ORX}+\mathrm{E}, 0.625 \mu \mathrm{g} / \mathrm{SILASTIC}$ [Dow Corning] capsule) at the time of surgery. Postoperative analgesia was provided by a long-acting local anesthetic ( $0.25 \%$ bupivacaine; $7.5 \mu \mathrm{l} /$ site; Abbott Laboratories). All procedures were approved by the Animal Care and Use Committee of the University of Virginia and were conducted within the guidelines of the National Research Council's Guide for the Care and Use of Laboratory Animals.

Brain slice preparation. All chemicals were from Sigma unless noted otherwise. Brain slices were prepared using modifications (Chu and Moenter, 2005) of a previously described method (Nunemaker et al., 2002). Briefly, all solutions were bubbled with a $95 \% \mathrm{O}_{2}-5 \% \mathrm{CO}_{2}$ mixture throughout the experiments and for at least 15 min before exposure to the tissue. The brain was rapidly removed and placed in ice-cold, high-sucrose saline solution containing $250 \mathrm{~mm}$ sucrose, $3.5 \mathrm{~mm} \mathrm{KCl,} 26$ mu $\mathrm{NaHCO}_{3}, 10 \mathrm{~mm}$ glucose, $1.25 \mathrm{~mm} \mathrm{Na}_{2} \mathrm{HPO}_{4}, 1.2 \mathrm{~mm} \mathrm{MgSO}_{4}$, and $2.5 \mathrm{mM} \mathrm{MgCl}_{2}$. Coronal $300 \mu \mathrm{m}$ brain slices were cut with a Vibratome 3000 (Technical Products International). Slices were incubated for 30 min at $30-32^{\circ} \mathrm{C}$ in a solution of $50 \%$ high-sucrose saline and $50 \%$ artificial CSF (ACSF) containing $135 \mathrm{~mm} \mathrm{NaCl}, 26 \mathrm{~mm} \mathrm{NaHCO}_{3}, 3.5 \mathrm{~mm}$ $\mathrm{KCl}, 10 \mathrm{~mm}$ glucose, $1.3 \mathrm{~mm} \mathrm{Na}_{2} \mathrm{HPO}_{4}, 1.2 \mathrm{~mm} \mathrm{MgSO}_{4}$, and $2.5 \mathrm{~mm}$ $\mathrm{CaCl}_{2}, \mathrm{pH} 7.4$, and were then transferred to a solution of $100 \%$ ACSF at room temperature and kept at least $30 \mathrm{~min}$ and no more than $6 \mathrm{~h}$ before recording.

Whole-cell recording and data collection. Brain slices were placed in a recording chamber continuously superfused with oxygenated ACSF solution at 5-6 $\mathrm{ml} / \mathrm{min}$ and kept at $32^{\circ} \mathrm{C}$ and mounted on an Olympus BX51WI upright fluorescent microscope with infrared differential interference contrast. GFP-GnRH neurons in the preoptic area and ventral hypothalamus were identified by brief illumination at $470 \mathrm{~nm}$. Data were recorded using MultiClamp 700B amplifier running Clampex 9.2 software, with signals low-pass filtered at $10 \mathrm{kHz}$ and digitized by a Digidata 1332A (Molecular Devices). Input resistance $\left(R_{\mathrm{in}}\right)$, series resistance $\left(R_{\mathrm{s}}\right)$, and membrane capacitance $\left(C_{\mathrm{m}}\right)$ were intermittently monitored by current response to $5 \mathrm{mV}$ hyperpolarizing step in membrane potential from a holding potential of $-60 \mathrm{mV}$. Only recordings with $R_{\text {in }}>500 \mathrm{M} \Omega$, $R_{\mathrm{s}}<20 \mathrm{M} \Omega$, and stable $C_{\mathrm{m}}$ are used for analysis. The location of each $\mathrm{GnRH}$ neuron studied was mapped on figures of sections obtained from a mouse brain atlas (Paxinos and Franklin, 2001). There was no differ- ence in control PSC frequency or responses to treatments among neurons from different anatomical location. No more than three cells per animal were recorded.

GABAergic PSCs. To isolate GABAergic currents, APV [D-(-)-2-amino-5phosphonovaleric acid] $(20 \mu \mathrm{M})$ and 6-cyano-7-nitroquinoxaline (CNQX; $20 \mu \mathrm{M}$ ) were included in the bath solution to block ionotropic glutamatergic currents. Recording pipettes (2-5 M $\Omega$ ) were filled with isotonic chloride pipette solution (140 mM KCl, 10 mM HEPES, 5 mM EGTA, and $0.1 \mathrm{~mm} \mathrm{CaCl}_{2}$ ) with the addition of $4 \mathrm{~mm} \mathrm{MgATP}$ and $0.4 \mathrm{~mm}$ NaATP before adjusting to $\mathrm{pH} 7.3$ with $\mathrm{NaOH}$. Membrane potential was clamped at $-60 \mathrm{mV}$; under these conditions, $\mathrm{GABA}_{\mathrm{A}} \mathrm{R}$-mediated PSCs recorded appear as inward currents. GABA PSCs were recorded over four $120 \mathrm{~s}$ control periods, then for four $120 \mathrm{~s}$ periods during bath application of $20 \mathrm{nM}$ or $2 \mu \mathrm{M} \mathrm{GnRH}$, followed by four $120 \mathrm{~s}$ periods of wash out. There was a 5 min perfusion period in between treatments to allow for exchange of bath solutions.

Glutamatergic PSCs. To isolate glutamatergic currents, picrotoxin (100 $\mu \mathrm{M})$ was included in the bath solution to block ionotropic GABAergic currents. Recording pipettes (2-5 M $\Omega$ ) were filled with Cs gluconate pipette solution ( $125 \mathrm{~mm}$ D-gluconic acid, $125 \mathrm{~mm} \mathrm{CsOH}, 25 \mathrm{~mm} \mathrm{CsCl}, 10$ mM HEPES, $1 \mathrm{~mm}$ EGTA, and $0.1 \mathrm{~mm} \mathrm{CaCl}_{2}$ ) with the addition of $4 \mathrm{~mm}$ MgATP and $0.4 \mathrm{~mm}$ NaATP before adjusting to $\mathrm{pH} 7.3$ with $\mathrm{CsOH}$. Membrane potential was clamped at $-70 \mathrm{mV}$; under these conditions, $\alpha$-amino-3-hydroxy-5-methyl-4-isoxazolepropionic acid-type glutamate receptor/kainite (AMPA/KA)-mediated PSCs recorded appear as inward currents. The recording sequence for testing effect of $\mathrm{GnRH}$ on glutamatergic EPSCs was the same as for GABAergic PSCs indicated above.

Pertussis toxin treatment. To test for $\mathrm{G}_{\alpha \mathrm{i}} / \mathrm{G}_{\alpha \mathrm{o}}$-dependent actions of $\mathrm{GnRH}$, slices were preincubated for at least $4 \mathrm{~h}$ at room temperature in PTX ( $5 \mu \mathrm{g} / \mathrm{ml}$, a kind gift from Dr. Erik Hewlett (University of Virginia, Charlottesville, VA) and List Biological Laboratories) as previously described (DeBock et al., 2003).

Analysis. Each 120 s recording of PSCs or EPSCs was analyzed off-line using MiniAnalysis event detection software (Synaptosoft). Events were confirmed by eye, and detection errors were corrected manually. The mean event frequency (in hertz) was calculated from four $120 \mathrm{~s}$ records for each cell to obtain the mean event frequency for each cell for each treatment period. Cells with $>25 \%$ change of PSC frequency in either direction in response to $\mathrm{GnRH}$ treatment were defined as responding cells. Average PSC amplitude was calculated for each treatment period. Averaged current waveforms were generated for each treatment period after aligning events on the rising phase and were used to illustrate differences in PSC amplitude.

Data were transferred to Excel (Microsoft) or Prism (GraphPad) for statistical analysis. Group means for intact, ORX and ORX+E PSC frequency were compared using Kruskal-Wallis nonparametric ANOVA followed by Dunn's multiple comparison post hoc test. Pairwise comparisons between control and GnRH treatments were performed using twotailed paired $t$ tests or Wilcoxon matched pairs tests as dictated by data distribution. Data are presented as mean \pm SEM. Cumulative probability plots were created by using 100 randomly selected events before and after treatment or all events if $<100$ were recorded. Probability distributions were compared using two-sample Kolmogorov-Smirnov goodness of fit tests (S-PLUS 2000, MathSoft). Statistical significance was set at $p<0.05$.

Double-label in situ hybridization for digoxigenin-GAD $D^{67}$ and ${ }^{33} P$ GnRHR-I mRNAs. Double-label in situ hybridization (ISH) was performed to determine whether GABAergic neurons in the medial preoptic area (mPOA) express GnRHR-1 mRNA. Fresh frozen coronal brain sections [ $25 \mu \mathrm{m}$, one-in-three series; covering the entire rostral to caudal extent of the organum vasculosum of the lamina terminalis (OVLT) to the $\mathrm{mPOA}$ ] from intact or ORX male mice were used in this study; no differences were observed as a result of gonadal status. Probe synthesis, the specificity of the complementary RNA (cRNA) probes, and procedures for ISH have been described previously (Chen et al., 1999). Briefly, $\mathrm{GAD}^{67}$ antisense cRNA probe was transcribed from a 220 bp rat cDNA using digoxigenin (dig)-UTP (Roche Molecular Biochemicals). The antisense mouse GnRHR-1 cRNA probes were transcribed from a 545-bp cDNA using ${ }^{33} \mathrm{P}$-labeled UTP as $25 \%$ of the total UTP (Perkin-Elmer). 
The specific activity of the probe was $5-6 \times 10^{9} \mathrm{dpm} / \mu \mathrm{g}$. Mounted brain sections were fixed in $4 \%$ paraformaldehyde and treated with a fresh solution containing $0.25 \%$ acetic anhydride in $0.1 \mathrm{~m}$ triethanolamine, $\mathrm{pH}$ 8.0 , followed by a rinse in $2 \times \mathrm{SSC}$, dehydrated through a graded series of alcohols, delipidated in chloroform, rehydrated through a second series of alcohols, and then air dried. The slides were exposed to the mixture of ${ }^{33} \mathrm{P}$-GnRHR-1 $\left(9 \times 10^{7} \mathrm{cpm} / \mathrm{ml}\right)$ and dig-GAD ${ }^{67}(2 \mu \mathrm{g} / \mathrm{ml})$ cRNA probes in moist chambers at $55^{\circ} \mathrm{C}$ for $15 \mathrm{~h}$. After incubation, the tissue sections were washed in SSC that increased in stringency, in RNase, in $0.1 \times \mathrm{SSC}$ at $60^{\circ} \mathrm{C}$, and then were incubated in alkaline phosphatase (AP) conjugated sheep anti-digoxigenin antibody (1:1000, Roche Molecular Biochemicals) at $4^{\circ} \mathrm{C}$ overnight. The AP-complexes were visualized with a mixture of nitroblue tetrazolium (NBT) and 5-bromo-4-chloro-3inodyl phosphate toluidinum. Slides were then dipped in 3\% Parlodion followed by NTB emulsion (Eastman Kodak Company), exposed for $30 \mathrm{~d}$ at $4^{\circ} \mathrm{C}$. The slides were developed, coverslipped with DPX mounting medium (BDH Chemicals).

Triple-label in situ hybridization immunohistochemistry for digoxigenin$G A D^{67},{ }^{33} P-G n R H R-I m R N A s$, and GFP-GnRH immunoreactivity. To investigate the anatomical relationship among $\mathrm{GnRH}$ neurons, GABAergic neurons and GnRHR-1-expressing neurons in the mPOA, triple-label ISH immunohistochemistry (IHC) was performed. Free-floating coronal brain sections ( $25 \mu \mathrm{m}$, one-in-three series; covering the entire rostral to caudal extent of the OVLT to the mPOA) from intact or ORX male GFP-GnRH mice were used in this study. Tissue sections were rinsed in $0.05 \mathrm{~m}$ potassium PBS (KPBS) followed by treatment with $1 \% \mathrm{NaBH}_{4}-$ KPBS solution. An antibody against GFP was used to label GnRH neurons since previous work with dual-label IHC demonstrates that GFP identifies GnRH neurons with high fidelity (Suter et al., 2000). Sections were incubated in rabbit anti-GFP antibody (1:30,000, Invitrogen) in KPBS with $0.4 \%$ Triton X-100 (KPBSX) for $48 \mathrm{~h}$. After incubation, the tissue was rinsed in KPBS and incubated in biotinylated donkey antirabbit IgG (1:600, Jackson ImmunoResearch Laboratories) in KPBSX for $1 \mathrm{~h}$ at room temperature. This was followed by $1 \mathrm{~h}$ incubation at room temperature in avidin-biotin complex solution (1:222, Vectastain ABC elite kit, Vector Laboratories). The GFP antibody-peroxidase complex was visualized with a mixture of 3,3-diaminobenzidine $(0.2 \mathrm{mg} / \mathrm{ml})$ and $3 \% \mathrm{H}_{2} \mathrm{O}_{2}(0.83 \mu \mathrm{l} / \mathrm{ml})$ in $0.05 \mathrm{M}$ Tris buffer-saline solution. When the staining was appropriate, the tissue was rinsed in KPBS, mounted on gelatin coated glass slides, and air dried overnight. The GFP-GnRHlabeled brain section slides were then processed for the same dig-GAD ${ }^{67}$ and ${ }^{33} \mathrm{P}$-GnRHR-I double-label ISH described in the above section.

The distribution of GnRH-, GAD ${ }^{67}$-, and GnRHR-1-positive neurons was analyzed by optical microscopy in the mPOA [coronal plate 22-31 (Paxinos and Franklin, 2001)], where GnRH neurons localize (Silverman, 1994). GnRH- and $\mathrm{GAD}^{67}$-positive neurons were visualized under brightfield as brown and purple blue deposits in the cytoplasm, respectively, whereas GnRHR-1-positive neurons in the same area were identified under brightfield as clusters of silver grains (appear as black color under brightfield). A GAD ${ }^{67}$ neuron was considered to be double-labeled with GnRHR-1 if the number of silver grains on top of the cell body was greater than three times the background level (Standish et al., 1987).

The numbers of $\mathrm{GAD}^{67}$-, GnRHR-1-positive, and $\mathrm{GAD}^{67} / \mathrm{GnRHR}-1$ coexpressing neurons were counted and analyzed in $\mathrm{mPOA}$ and prefrontal cortex areas. Both $\mathrm{GAD}^{67}$ and GnRHR-1 mRNA have been reported to express in prefrontal cortex area (Esclapez et al., 1993; Jennes and Conn, 1994); therefore, this area was selected for comparison with the mPOA, which, in addition, contains GnRH neurons and fibers. The 25 $\mu \mathrm{m}$ coronal brain sections were anatomically matched across animals. An individual brain section image was captured by a charge-coupled device camera (Cohu) and displayed on a computer monitor. A marked area $(280 \times 200 \mu \mathrm{m})$ was drawn to include the unilateral side of $\mathrm{mPOA}$ and prefrontal cortex. The marked area was constant for all the sections analyzed. The numbers of $\mathrm{GAD}^{67}$-, GnRHR-1-positive, and $\mathrm{GAD}^{67}$ / GnRHR-1 coexpressing neurons were counted visually with a counter. Each data point is the sum of two brain sections per area per animal and expressed as number of cells/2,800,000 $\mu \mathrm{m}^{3}(280 \times 200 \times 50 \mu \mathrm{m})$.

\section{Results}

GAD $^{67}$ and GnRHR-1 are colocalized in the mPOA

$\mathrm{GAD}^{67}$ mRNA containing neurons were identified under brightfield as blue-purple deposits in the cytoplasm. As previously reported (Esclapez et al., 1993), GAD ${ }^{67}$-positive neurons were found throughout the brain, including the cortex, hippocampus, striatum, and the hypothalamus. Within the mPOA, a high density of GAD ${ }^{67}$-labeled cells $\left(278 \pm 12\right.$ cells $/ 2,800,000 \mu \mathrm{m}^{3}, n=6$ mice) was found throughout the region. Only sparse GnRHR-1 mRNA signal $\left(6.3 \pm 1.7\right.$ cells $\left./ 2,800,000 \mu \mathrm{m}^{3}, n=6\right)$, which is represented by silver grain clusters, was found in the same area. However, $75 \pm 6 \%$ of those GnRHR-1-positive neurons also express GAD ${ }^{67}$ mRNA (4.6 \pm 0.9 double-labeled cells/2,800,000 $\mu \mathrm{m}^{3}, n=6$ ) (Fig. $1 B$ ). Two percent of $\mathrm{GAD}^{67}$-positive neurons coexpress GnRHR1 in the mPOA; in contrast, no double labeling was detected in the prefrontal cortex despite detection of each individual label (GAD ${ }^{67}$-positive neurons $247.1 \pm 10.9$ cells/ 2,800,000 $\mu^{3}{ }^{3}$,GnRHR-1-positive neurons $0.92 \pm 0.3$ cells/ $\left.2,800,000 \mu \mathrm{m}^{3}, n=6\right)$. To examine the relative anatomical locations of $\mathrm{GAD}^{67}$ - and GnRHR-1-positive neurons to the GnRH neurons in the mPOA, we performed triple-label ISH/IHC to simultaneously detect the three types of neurons. Even with this less sensitive detection method, comparable amounts of GAD ${ }^{67}$ and GnRHR-1 neurons were labeled as with double-label ISH procedure. We found GnRH neurons were surrounded by $\mathrm{GAD}^{67}$-positive neurons; and some $\mathrm{GAD}^{67} / \mathrm{GnRHR}-1$ doublelabeled neurons were found in proximity to GnRH neurons or GnRH-ir fiber process (Fig. $1 C$, lower magnification; $D-F$, higher magnification). Moreover, some GnRH neurons were also found to express GnRHR-1 (data not shown), in agreement with a previous report showing the mRNA transcripts of $\mathrm{GnRH}$ and GnRHR-1 were detected from the same neuron using single cell RT-PCR technique (Xu et al., 2004; Todman et al., 2005). To eliminate the possibility that the low levels of GnRHR-1 signal is attributable to the ineffectiveness of cRNA probe sequence in detecting GnRHR-1 mRNA, we applied the same probe to mouse pituitary and observed a high density of GnRHR-1 mRNA signal (Fig. 1A) as reported by others (Smith and Reinhart, 1993; Fraser et al., 1996). In summary, these anatomical data showed abundant GABAergic neurons in the vicinity of GnRH neuronal soma. Low levels of GnRHR-1 mRNA were found in the same area; however, the majority of those GnRHR-1-positive neurons were GABAergic.

\section{ORX increases and estradiol treatment restores the frequency of GABAergic transmission to $\mathrm{GnRH}$ neurons}

To examine whether GABAergic transmission to GnRH neurons in males is affected by steroid milieu, spontaneous GABAergic postsynaptic currents (PSCs) were recorded from GFP-identified GnRH neurons in brain slices obtained from intact and ORX mice. Bicuculline eliminated all PSCs, demonstrating that they are mediated by the $\mathrm{GABA}_{\mathrm{A}}$ receptor (data not shown). Representative recordings are shown in Figure $2 A$. ORX enhanced the frequency of GABA transmission to GnRH neurons (Fig. 2B) (ORX $n=33$ cells from 24 animals, intact, $n=33$ cells from 25 animals, $p<0.05)$. Estradiol has been shown to mediate central negative feedback on $\mathrm{GnRH}$ neuron activity in male mice (Pielecka and Moenter, 2006). To test the hypothesis that estradiol reverses the effect of ORX on GABAergic transmission, spontaneous GABAergic PSCs were recorded from ORX $+\mathrm{E}$ animals. GABAergic PSCs frequency in ORX +E males was not different from intact controls, and significantly reduced from ORX males (Fig. $2 A, B$ ) (intact $n=33$ cells from 25 animals; ORX $+\mathrm{E}$ 
$n=11$ cells from 6 animals, $p<0.05$ vs ORX). Neither ORX (Fig. 2C,D) nor estradiol (data not shown) altered the amplitude of spontaneous PSCs. These results are consistent with previous data indicating GABA can excite GnRH neurons (DeFazio et al., 2002), and suggest the GABAergic system is a mediator of gonadal feedback regulation of GnRH neuronal activity in male mice.

\section{Low-dose (20 nM) GnRH reduces GABAergic transmission to GnRH neurons}

To test the hypothesis that the inhibitory effect of low-dose GnRH treatment on GnRH neuron firing rate is attributed to network interactions altering fast synaptic transmission, spontaneous GABAergic PSCs were recorded from $\mathrm{GnRH}$ neurons in brain slices from ORX and intact males. We focused on GABA for two reasons. First, the anatomical results above suggest a majority of GnRHR-1 expression in the vicinity of GnRH neurons is on GABAergic neurons. Second, the basal level of glutamatergic transmission in GnRH neurons in slices is very low with some cells receiving no detectable currents (Suter, 2004; Christian et al., 2009). Representative traces of GABAergic PSCs are shown in Figure $3 A, B$. Treatment with $20 \mathrm{~nm} \mathrm{GnRH}$ reduced GABAergic transmission to GnRH neurons from intact males overall (Fig. $3 A, C)(p<0.01, n=19$ cells from 14 animals). Of the 19 cells examined, 10 (53\%) exhibited the $25 \%$ change in PSC frequency required to be considered as responding, a percentage similar to the percentage of GnRH neurons inhibited by this dose of $\mathrm{GnRH}$ in a previous study $(\mathrm{Xu}$ et al., 2004). Among cells with $>25 \%$ change in GABAergic PSC frequency, 20 nM suppressed GABAergic PSCs frequency by $57 \pm 3 \%(p<0.01)$. In ORX mice, 20 nM GnRH similarly reduced GABAergic transmission to GnRH neurons (Fig. $3 B, C)(p<0.05, n=22$ cells from 16 animals). Among the cells with $>25 \%$ change in PSC frequency (12 of 22 neurons), $20 \mathrm{~nm}$ GnRH suppressed GABAergic PSC frequency by $59 \pm 3 \%$. There was no difference in control PSC frequency ( $p=0.35$ ) or anatomical location between responding and nonresponding cells from either intact or ORX mice, and both responding and nonresponding cells were found in slices from the same animal. Preincubation with 10 nM GnRH receptor antagonist ([D-pGlu ${ }^{1}$ D-Phe ${ }^{2}$-D-Trp $\left.{ }^{3,6}\right]$-LHRH) abolished the effect of GnRH in ORX animals $(0.6 \pm 0.1$ $\mathrm{Hz}$ vs $0.7 \pm 0.1 \mathrm{~Hz}, p=0.7, n=8$ cells

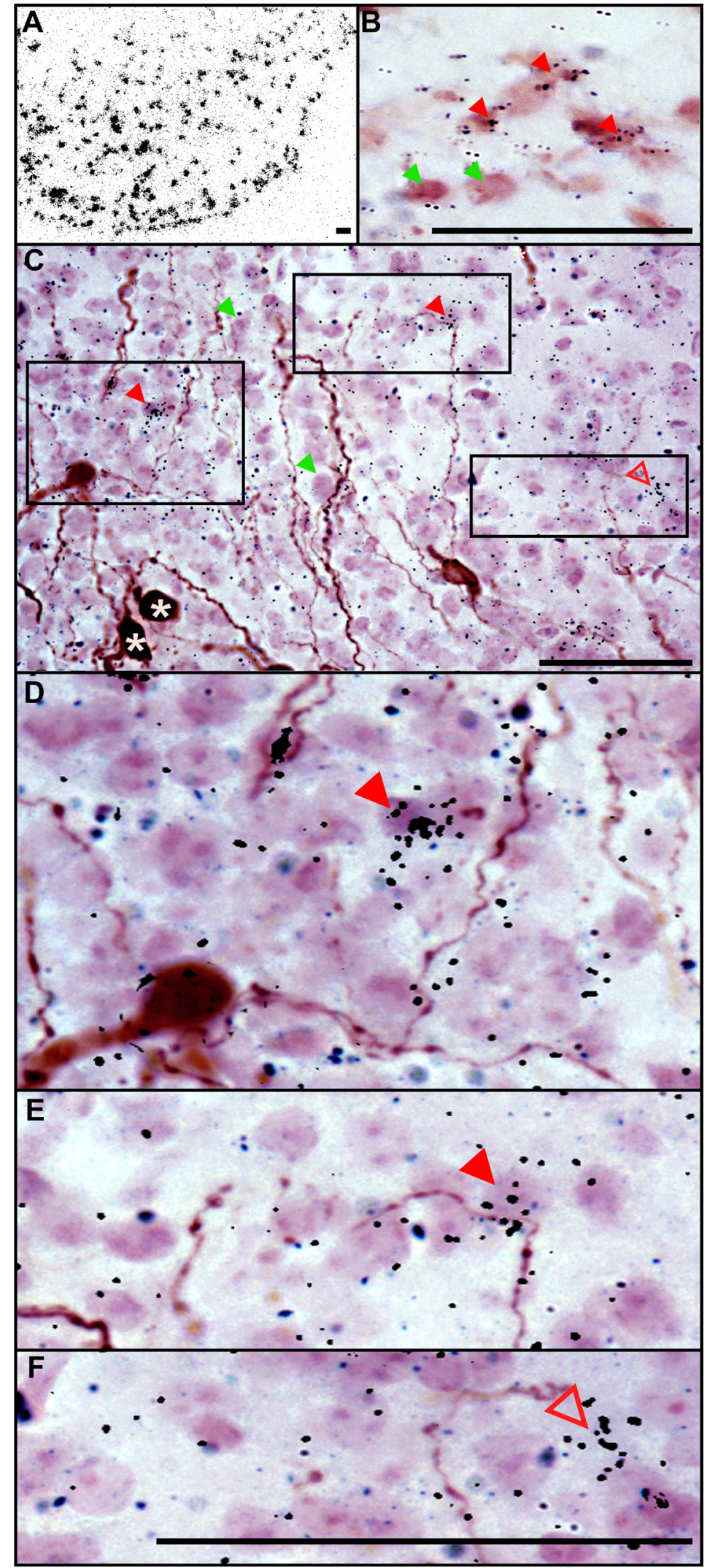

Figure 1. $\mathrm{GAD}^{67}$, GnRHR-1, and GnRH triple labeling in the MPOA. $A$, Representative brightfield photomicrograph showing dense clusters of GnRHR-1 mRNA (silver grain clusters) in a mouse pituitary section. $\boldsymbol{B}$, Representative photomicrograph showing the double-label of $G A D{ }^{67} \mathrm{mRNA}$ signal (blue-purple staining), the GnRHR-1 mRNA signal (silver grain clusters) used for quantification. C, Triple label adding $\mathrm{GnRH}$ immunoreactivity (brown precipitation) in the same area in the $\mathrm{mPOA}$. D-F, Higher magnification of the boxed areas shown in $C$. Solid red arrowheads indicate representative $G A D^{67} / G$ nRHR-1 double-labeled neurons (in $B-E$ ). Single-labeled $G A D^{67}$ neurons are indicated by green arrowheads (in $\boldsymbol{B}$ and $\boldsymbol{C}$. Single-labeled GnRHR-1 neurons are indicated by red empty arrowheads (in $\boldsymbol{C}$ and $\boldsymbol{F}$ ), respectively. GnRH neuronal soma are denoted with white asterisk $\left(^{*}\right)$.Scale bars, $50 \mu \mathrm{m}$. 


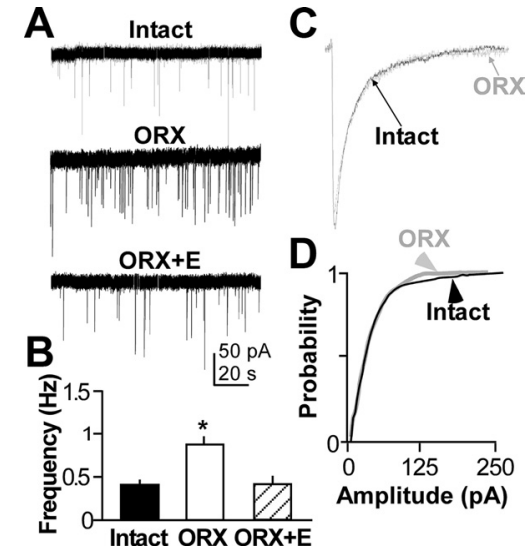

Figure 2. ORX enhances frequency of spontaneous GABAergic transmission to GnRH neurons but does not alter current amplitude. $A$, Representative PSC recordings from GnRH neurons from intact (top), ORX (middle), and ORX $+\mathrm{E}$ (bottom) animals. $\boldsymbol{B}$, Mean \pm SEM spontaneous PSC frequency (in hertz) in GnRH neurons from intact ( $n=33$ cells), $\mathrm{ORX}$ ( $n=33$ cells), and ORX $+\mathrm{E}$ $(n=11$ cells) males. C, Averaged PSC traces from representative ORX and intact males. $\boldsymbol{D}$, Cumulative probability distribution for PSC amplitude comparing events between ORX and intact males (intact $n=960 \mathrm{PSC}$ vs $0 \mathrm{RXX} n=1023 \mathrm{PSC}, p=0.4$ ). ${ }^{*} p<0.05$ versus intact and $\mathrm{ORX}+\mathrm{E}$.

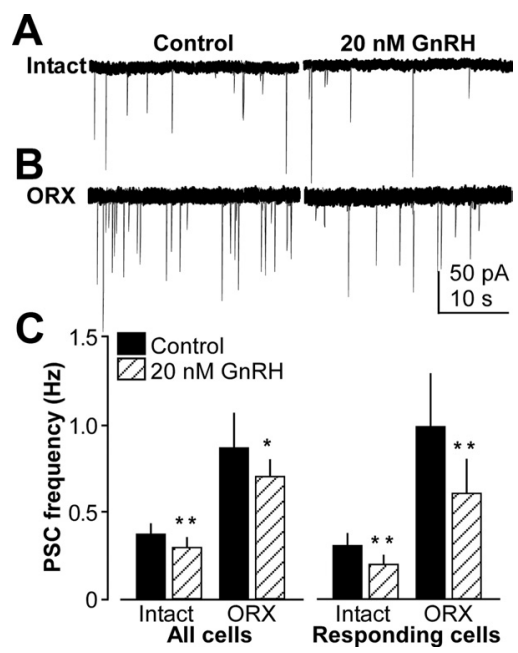

Figure 3. Treatment with low-dose $(20 \mathrm{~nm}) \mathrm{GnRH}$ reduces frequency of spontaneous GABAergic transmission to GnRH neurons. $A, B$, Representative GABAergic PSC recordings from responding $\mathrm{GnRH}$ neurons from intact $(\boldsymbol{A})$ and $\mathrm{ORX}(\boldsymbol{B})$ males before and during $20 \mathrm{~nm} \mathrm{GnRH}$ treatment. C, Mean \pm SEM spontaneous PSC frequency from combined responding and nonresponding cells from intact $(n=19)$ and $\mathrm{ORX}(n=22)$ mice; and responding cells from intact $(n=10)$ and ORX $(n=12)$ mice. ${ }^{*} p<0.05$ versus control, ${ }^{* *} p<0.01$ versus control.

from 4 ORX animals), confirming this effect is mediated through GnRHR-1. There was no difference in GABAergic PSC frequency between control and $\mathrm{GnRH}$ antagonist treatment $(0.6 \pm 0.1 \mathrm{~Hz}$ vs $0.6 \pm 0.1 \mathrm{~Hz}, p=0.2, n=8$ cells from 4 ORX animals). These results support the hypothesis that low-dose GnRH suppresses $\mathrm{GnRH}$ firing rate at least in part via decreasing GABA transmission to the GnRH neurons, and further suggest the effect of $\mathrm{GnRH}$ via this mechanism is not dependent on gonadal hormone milieu.

High-dose ( $2 \mu \mathrm{M}) \mathrm{GnRH}$ has no effects on GABAergic transmission to GnRH neurons

To test the hypothesis that increases in GABAergic transmission mediates the stimulatory effect of GnRH on GnRH firing activity, we recorded GABAergic PSCs from GnRH neurons before and

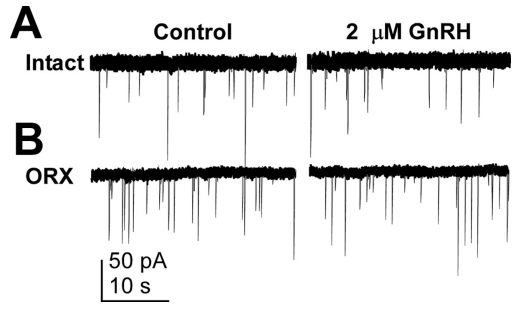

Figure 4. Treatment with high-dose $(2 \mu \mathrm{m}) \mathrm{GnRH}$ has no effect on frequency of spontaneous GABAergic transmission to GnRH neurons. $\boldsymbol{A}, \boldsymbol{B}$, Representative GABAergic PSC recordings from $\mathrm{GnRH}$ neurons from intact $(\boldsymbol{A})$ and $\mathrm{ORX}(\boldsymbol{B})$ animals.

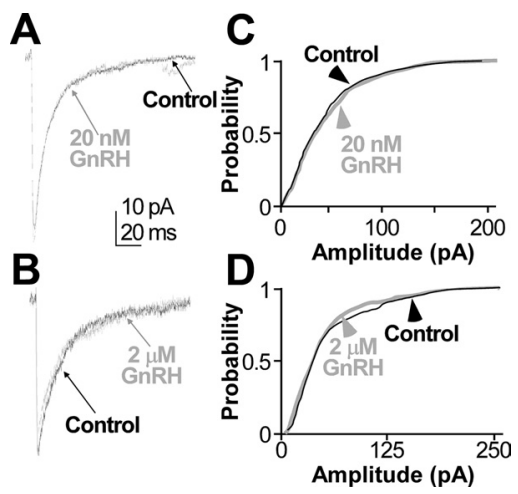

Figure 5. Neither low nor high doses of GnRH alters GABAergic PSC amplitude. $A, B$, Averaged PSC traces during the control period and treatment with $20 \mathrm{~nm} \mathrm{GnRH}(\boldsymbol{A})$ or $2 \mu \mathrm{m} \mathrm{GnRH}(\boldsymbol{B})$. $C, D$, Cumulative probability distribution for PSC amplitude comparing events between treatments ( $\boldsymbol{C}$, control $n=759$ PSCs, $20 \mathrm{~nm} \mathrm{GnRH}, n=710$ PSCs; $\boldsymbol{D}$, control $n=672$ PSCs, $2 \mu \mathrm{m}$ $\mathrm{GnRH} n=660 \mathrm{PS}(\mathrm{s})$.

during treatment with $2 \mu \mathrm{M}$ GnRH. Remarkably, $2 \mu \mathrm{M}$ GnRH had no effect on the frequency of GABAergic transmission to GnRH neurons from ORX or intact mice (Fig. 4) (ORX control $0.9 \pm 0.2 \mathrm{~Hz}$ vs $2 \mu \mathrm{M} \mathrm{GnRH} 0.9 \pm 0.2 \mathrm{~Hz}, p=0.86, n=11$ cells from 8 animals; or intact control $0.4 \pm 0.1 \mathrm{~Hz}$ vs $2 \mu \mathrm{M} \mathrm{GnRH}$ $0.4 \pm 0.1 \mathrm{~Hz}, p=0.66, n=14$ cells from 10 animals). These results do not support the hypothesis that higher levels of $\mathrm{GnRH}$ stimulate $\mathrm{GnRH}$ neurons via increased GABAergic transmission, and suggest the stimulatory effect of high-dose GnRH on GnRH firing activity may be mediated by other fast synaptic transmission to GnRH neurons, such as glutamatergic synaptic inputs, or via neuromodulation or intrinsic mechanisms.

\section{GnRH does not alter amplitude of GABAergic PSCs in GnRH neurons}

In addition to frequency, we also analyzed amplitude of PSCs to determine whether either dose of $\mathrm{GnRH}$ altered the response of GnRH neurons to $\mathrm{GABA}_{\mathrm{A}} \mathrm{R}$ activation. GnRH treatment at $20 \mathrm{nM}$ had no effect on PSC amplitude (Fig. 5). Although $2 \mu \mathrm{M} \mathrm{GnRH}$ treatment caused a small decrease in the mean amplitude of PSCs compared with the control (Fig. 5B), this small change most likely reflects a $10 \%$ increase in series resistance observed between the control and treatment period in this group, rather than a physiological phenomenon.

High-dose ( $2 \mu \mathrm{M}) \mathrm{GnRH}$ has no effect on glutamatergic transmission to $\mathrm{GnRH}$ neurons

Because we observed no effect of $2 \mu \mathrm{M}$ GnRH on GABAergic transmission, we tested the hypothesis that the stimulatory effect of high-dose $\mathrm{GnRH}$ is mediated by increased glutamatergic transmission to GnRH neurons. Glutamatergic EPSCs mediated by 


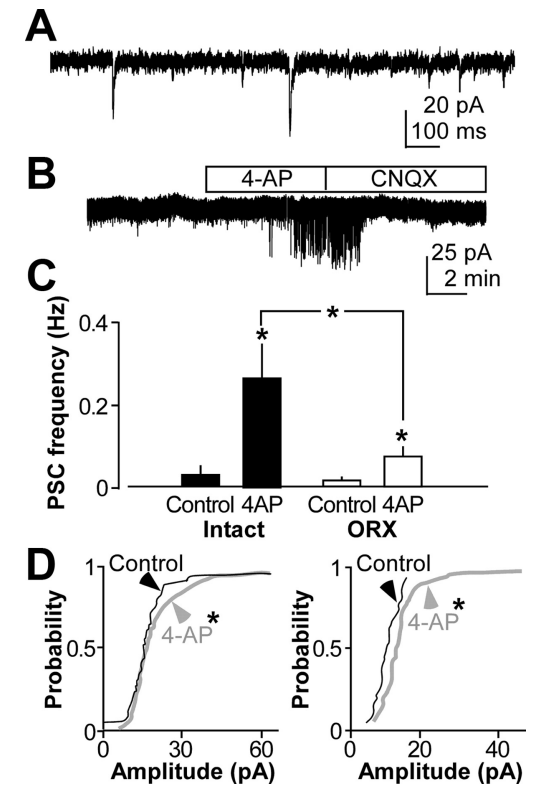

Figure 6. GnRH does not alter glutamatergic transmission to GnRH neurons from intact or ORX mice, but gonadal status affects availability of stimulated transmission. $\boldsymbol{A}$, Representative trace of spontaneous glutamatergic EPSCs from a GnRH neuron. $\boldsymbol{B}$, A representative trace showing that the potassium channel inhibitor 4-AP (1 mM) increases frequency and amplitude of EPSCs recorded from GnRH neurons and that CNQX abolishes these EPSC. C, Mean \pm SEM frequency of 4-AP-stimulated glutamatergic transmission in cells from intact ( $n=5$ cells) and ORX ( $n=5$ cells) mice. $D$, Probability distribution of EPSC amplitude from intact (left) and ORX mice before and during treatment with 4-AP (intact control $n=154$ EPSCs, 4-AP $n=497$ EPSCs; 0RX control $n=29$ EPSCs, 4-AP $n=170$ EPSCs). ${ }^{*} p<0.05$.

AMPA/KA receptors were recorded from $\mathrm{GnRH}$ neurons before and during treatment with $2 \mu \mathrm{M} \mathrm{GnRH}$ in slices from ORX and intact mice. Compared with GABAergic transmission to $\mathrm{GnRH}$ neurons, AMPA/KA-mediated glutamatergic transmission is less frequent and smaller in amplitude (Fig. 6A). In contrast to the marked effect of ORX on GABA transmission, there was no difference $(p=0.76)$ in spontaneous glutamatergic transmission to GnRH neurons from ORX $(0.11 \pm 0.04 \mathrm{~Hz}, n=28$ cells from 22 animals $)$ or intact $(0.08 \pm 0.04 \mathrm{~Hz}, n=13$ cells from 10 animals) mice. Likewise, glutamatergic transmission to $\mathrm{GnRH}$ neurons was not affected by $2 \mu \mathrm{M} \mathrm{GnRH}$ in intact (control $0.08 \pm 0.04 \mathrm{~Hz}$ vs $2 \mu \mathrm{M} \mathrm{GnRH} 0.12 \pm 0.06 \mathrm{~Hz}, p=$ $0.39, n=13$ cells from 10 animals) or in ORX mice (control $0.17 \pm 0.06 \mathrm{~Hz}$ vs $2 \mu \mathrm{M}$ GnRH $0.19 \pm 0.06 \mathrm{~Hz}, p=0.56, n=$ 14 cells from 12 animals).

Interestingly, under these recording conditions, in which $\mathrm{K}^{+}$ conductances are blocked with $\mathrm{Cs}^{+}$to enhance membrane potential stability and detection of EPSCs, we observed a significant increase in holding current to maintain membrane potential at $-70 \mathrm{mV}$ (control vs $2 \mu \mathrm{M} \mathrm{GnRH}-38.9 \pm 1.8 \mathrm{pA}$, vs $-50.9 \pm 3.3$ $\mathrm{pA}, p<0.01$ ), suggesting a possible direct effect on $\mathrm{GnRH}$ neurons to generate an excitatory inward current. No effect of GnRH on holding current was observed In GnRH neurons during recording of GABAergic PSCs (control vs $2 \mu \mathrm{M}$ GnRH: $-26.4 \pm 1.5$ vs $-24,7 \pm 2 \mathrm{pA}, p=0.4 ; 588 \pm 14$ vs $570 \pm 17 \mathrm{~m} \Omega, p=0.2$ ), perhaps suggesting an opposing direct effect to enhance $\mathrm{K}^{+}$conductances. There was no effect of $\mathrm{GnRH}$ on input resistance of GnRH neurons under either condition, although as expected, input resistance was enhanced by the $\mathrm{Cs}+$ containing pipette solution (GABA PSC recording, control vs $2 \mu \mathrm{M}$ GnRH $588 \pm 14$ vs $570 \pm 17 \mathrm{~m} \Omega, p=0.2$; glutamatergic EPSC recording control vs $2 \mu \mathrm{M}$ GnRH $912 \pm 108$ vs $882 \pm 75 \mathrm{~m} \Omega, p=0.65)$.
The relatively low frequency of glutamatergic transmission to GnRH neurons is similar to a previous report (Suter, 2004), however, contrasts with an earlier report that essentially all GnRH neurons respond to AMPA receptor agonists directly applied to the cell (Spergel et al., 1999). This difference raises the question of whether or not GnRH neurons have glutamatergic synapses that are physically present but not active under our experimental conditions. To test this and confirm our ability to detect these currents when present, we treated slices with the potassium channel inhibitor 4-aminopyridine (4-AP, $1 \mathrm{~mm}$ ) to increase neuronal excitability and promote synaptic release to determine whether there are glutamatergic synapses on $\mathrm{GnRH}$ neurons that can be revealed. Treatment with 4-AP increased frequency and amplitude of EPSCs recorded from GnRH neurons (Fig. $6 B-D$ ). EPSCs were abolished by CNQX treatment indicating they are mediated by AMPA/KA receptors (Fig. 6B). Of interest, 4-AP-stimulated glutamatergic transmission in cells from intact mice $(n=5)$ was higher frequency $(p<0.05)$ than that in cells from ORX mice $(n=5)$ (Fig. 6C), suggesting gonadal steroid milieu impacts on glutamatergic synapses on GnRH neurons.

\section{$\mathrm{G}_{\alpha \mathrm{i}}$ mediates the inhibitory effect of low GnRH on GABAergic transmission to GnRH neurons}

Previous work suggests different concentrations of GnRH can engage different signaling systems (Krsmanovic et al., 2003). We hypothesized the concentration-dependent effects of $\mathrm{GnRH}$ on GnRH neuronal activity is mediated by coupling of GnRHR-1 to different $G_{\alpha}$ proteins. To test whether the inhibitory $G$ protein $\mathrm{G}_{\alpha \mathrm{i}}$ mediates the inhibitory effect of low GnRH on GABAergic transmission to GnRH neurons, we recorded PSCs of GnRH neurons from ORX brain slices that were pretreated at least $4 \mathrm{~h}$ with $\mathrm{G}_{\alpha \mathrm{i}} / \mathrm{G}_{\alpha \mathrm{o}}$-specific inhibitor PTX $(5 \mu \mathrm{g} / \mathrm{ml})$. To determine whether the prolonged incubation time needed for the PTX treatment altered the response to $20 \mathrm{nM} \mathrm{GnRH}$, we recorded control cells $(n=4)$ from brain slices that were incubated in normal saline at room temperature for $4 \mathrm{~h}$ or longer. Two of four non-PTXtreated cells responded to $20 \mathrm{~nm} \mathrm{GnRH}$ with a $>25 \%$ decrease in GABAergic PSC frequency (data not shown), a similar percentage as was observed with a shorter slice incubation time in Figure 3 above. In slices pretreated with PTX, however, 20 nM GnRH no longer reduced frequency of GABAergic transmission to any $\mathrm{GnRH}$ neuron examined, rather there was a trend toward an increased frequency (Fig. 7) (two-tailed $p=0.065, n=10$ cells from 7 animals). Interestingly, in the presence of PTX, $20 \mathrm{nM}$ $\mathrm{GnRH}$ increased the frequency of GABAergic PSCs in 3 of the 10 cells $(30 \%)$ examined, whereas in the absence of PTX only 2 of 38 cells $(5 \%)$ received increased transmission in response to this treatment. Of further interest, subsequent treatment of these same cells with high-dose $(2 \mu \mathrm{M}) \mathrm{GnRH}$ enhanced frequency of GABAergic transmission to GnRH neurons, with six of eight neurons receiving increased transmission (Fig. 7) $(p<0.01, n=8$, two of the cells that were treated with $20 \mathrm{~nm} \mathrm{GnRH}$ were not tested with $2 \mu \mathrm{M} \mathrm{GnRH}$ ). These data suggest GnRH-1 assumes different conformations that have different affinities when coupled to different $G$ proteins, resulting in ligand concentrationdependent changes in the signaling pathways activated.

\section{Discussion}

Synchronization of GnRH neurons to produce pulsatile release is prerequisite for fertility. The underlying mechanisms for coordinated release from the dispersed GnRH neuronal population remain to be determined. GnRH has been implicated as a mediator in synchronizing $\mathrm{GnRH}$ neurons since $\mathrm{GnRH}$ pulses persist in 


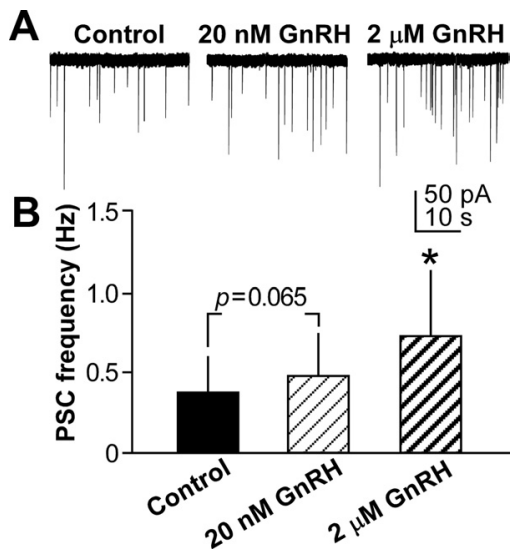

Figure 7. PTX treatment blocks the suppressive effect of $20 \mathrm{~nm} \mathrm{GnRH}$ and reveals a stimulatory effect of $2 \mu \mathrm{M} \mathrm{GnRH}$ on GABAergic transmission to $\mathrm{GnRH}$ neurons. $A$, Representative recording of GABAergic PSCs from a single PTX-treated GnRH neuron during the control period (left), $20 \mathrm{~nm}$ GnRH (center), and $2 \mu \mathrm{m}$ GnRH (right) treatments. $\boldsymbol{B}$, Mean \pm SEM spontaneous GABAergic PSC frequency (Hz) in response to $20 \mathrm{~nm}\left(n=10\right.$ cells) or $2 \mu \mathrm{m}$ ( $n=8$ cells). ${ }^{*} p<$ 0.05 versus control.

GnRH neuronal GT1-1 cell lines (Martínez de la Escalera et al., 1992; Krsmanović et al., 1993), and exogenous GnRH induces ultrashort loop inhibition of GnRH neurons in vivo and ex vivo (Bedran de Castro et al., 1985; DePaolo et al., 1987; Valença et al., 1987; Zanisi et al., 1987; Padmanabhan et al., 1995). Previously, GnRH was shown to modify the activity of adult mouse GnRH neurons in a concentration-dependent manner, with low doses inhibiting and high doses stimulating firing rate (Xu et al., 2004). There are at least two means, direct and transsynaptic, for GnRH action on $\mathrm{GnRH}$ neuronal activity. GnRH can directly modify activity of GnRH neurons by either depolarizing (Todman et al., 2005) or hyperpolarizing (Xu et al., 2008) membrane potential. Here, we identify a transsynaptic pathway for GnRH to regulate the activity of GnRH neurons via modifying GABAergic transmission to these cells.

The finding that most GnRHR-1 message within the mPOA is colocalized with synthetic enzymes for GABA provides an anatomical basis for regulation of GABAergic neurons by $\mathrm{GnRH}$. Neurons that coexpress GAD ${ }^{67}$ and GnRHR-1 were observed in the medial septum, OVLT, and anterioventral periventricular nucleus. Triple ISH and IHC labeling revealed the location of $\mathrm{GAD}^{67} / \mathrm{GnRHR}-1$ neurons relative to the GnRH neurons. Triple ISH and IHC labeling normally yields lower mRNA signals because of the additional histochemical processing. Even with this lower sensitivity method, GAD ${ }^{67} / \mathrm{GnRHR}$-1 double-labeled neurons were consistently observed in proximity to GnRH soma and processes, as were GnRH neurons expressing GnRHR-1. In addition, a small population of non-GABA or $\mathrm{GnRH}$ cells that express GnRHR-1 was identified, suggesting GnRH neurons may interact with other elements in local circuits. These findings support and extend previous reports that GnRHR-1 is expressed at low levels (Jennes and Conn, 1994), and is expressed on GnRH and nonGnRH neurons in mPOA (Xu et al., 2004).

We hypothesized low doses of GnRH (20 nM) would inhibit, whereas high doses of $\mathrm{GnRH}(2 \mu \mathrm{M})$ would stimulate GABA transmission to $\mathrm{GnRH}$ neurons, since activation of $\mathrm{GABA}_{\mathrm{A}}$ receptor can depolarize and even excite $\mathrm{GnRH}$ neurons to fire action potentials (DeFazio et al., 2002; Han et al., 2004). Low doses of GnRH suppressed GABAergic transmission to GnRH neurons, supporting the hypothesis. Approximately half of $\mathrm{GnRH}$ neurons tested showed reduced GABAergic transmission in response to
$20 \mathrm{~nm}$ GnRH treatment, similar to the percentage of neurons exhibiting reduced firing rate in response to this $\mathrm{GnRH}$ treatment (Xu et al., 2004). This differential response may indicate only a portion of GnRH neurons receive transmission from GnRHR-1expressing GABAergic afferents, as these are a small subpopulation of POA GABAergic neurons. It is also possible connections from GnRHR-1-expressing GABAergic neurons to $\mathrm{GnRH}$ neurons were severed during slice preparation, eliminating any GABA-mediated changes.

The hypothesized stimulatory effect of high doses of GnRH on GABAergic transmission to GnRH neurons was not observed. We thus tested the hypothesis that high doses of GnRH modify GnRH neuronal activity by increasing glutamatergic transmission, the other major fast synaptic input to GnRH neurons (Suter, 2004; Christian et al., 2009). High doses of GnRH, which increased GnRH neuronal activity in previous studies, did not affect spontaneous glutamatergic transmission to $\mathrm{GnRH}$ neurons under these experimental conditions.

For different concentrations of GnRH to induce different responses, both presynaptic and postsynaptic actions could be used. Although neither GABAergic nor glutamatergic transmission were altered by high-dose $\mathrm{GnRH}$, alternative mechanisms such as changes in neuromodulatory inputs that alter GnRH neuron activity via metabotropic receptors may be used. In this regard, the present and previous (Xu et al., 2004) data indicate GnRHR-I is expressed by non-GnRH non-GABAergic neurons. Another possibility is direct action of $\mathrm{GnRH}$ on $\mathrm{GnRH}$ neurons; the changes in holding current observed in the present report and previous studies indicate such direct action can contribute (Todman et al., 2005; Xu et al., 2008).

Another level of regulation is imposed by the observation that the $\mathrm{GnRH}$ receptor can couple to and regulate multiple $\mathrm{G}_{\alpha}$ proteins, including PTX-sensitive $G_{i}$ and $G_{o}$ (Hawes et al., 1993) and PTX-insensitive $\mathrm{G}_{\mathrm{q} / 11}$ (Hsieh and Martin, 1992) and $\mathrm{G}_{\mathrm{s}}$ (Weiss et al., 1987; Janovick and Conn, 1993). Studies using GT1 cells showed $\mathrm{GnRH}$ receptor activation in response to $\mathrm{GnRH}$ depended on both dose of $\mathrm{GnRH}$ and the G protein coupled to the receptor (Krsmanovic et al., 2003). GnRH has antiproliferative and apoptosis-inducing effects in human cancer cells, and these effects are mediated by the $\mathrm{G}_{\mathrm{i}}$-activated signaling cascade (Gründker et al., 2001). In the present study, preincubation with the $\mathrm{G}_{\alpha \mathrm{i} / \mathrm{o}}$ inactivator PTX blocked the suppressive effect of low doses of GnRH, even having a tendency to reverse the suppressive effects of low-dose GnRH. This suggests the inhibitory effect of $20 \mathrm{~nm} \mathrm{GnRH}$ on GABA transmission to $\mathrm{GnRH}$ neurons is mediated by $\mathrm{G}_{\alpha \mathrm{i}}$. Interestingly, after PTX treatment we also observed a stimulatory effect of $2 \mu \mathrm{M}$ GnRH on GABA PSCs of $\mathrm{GnRH}$ neurons. This suggests that at high concentrations, GnRH can bind to GnRHR-1 that is coupled to not only $\mathrm{G}_{\alpha \mathrm{i}}$ but also stimulatory $G_{\alpha}$ proteins, such as $G_{\alpha q / 11}$ or $G_{\alpha s}$. The simultaneous activation of both inhibitory and excitatory $G$ proteins might explain the lack of effect of high concentration $\mathrm{GnRH}$ on GABAergic transmission under control conditions (i.e., without $\mathrm{G}_{\alpha \mathrm{i}}$ blocked). Specifically, it is possible that the downstream effects of these signaling pathways negate one another within the cell. In this regard, by using different $\mathrm{GnRH}$ analogs that can access different binding pockets of GnRHR-1, work from Millar's group demonstrated that GnRHR-1 can assume different conformations that have different selectivity for GnRH analogs and recruit different intracellular signaling proteins complexes, resulting in a single class of receptor producing a variety of responses (López de Maturana et al., 2008; Millar et al., 2008; Pfleger et al., 2008). We propose a model in which this ligand- 
induced selective-signaling is one mechanism underlying the observed concentrationdependent coupling of GnRHR-1 to different G proteins (Fig. 8). High-affinity configurations will be preferentially activated when $\mathrm{GnRH}$ is present at low concentrations. When GnRH concentration is high enough to touch other lower affinity binding pockets, other $\mathrm{G}$ proteins are activated as well.

This concentration-dependent action of GnRH on GnRH neuronal activity could be an important mechanism for GnRH to modify its own release in different physiological conditions, specifically pulse versus surge mode. During pulsatile release, GnRH levels are likely lower and are not as sustained as during the surge. Under these conditions, an inhibitory action of $\mathrm{GnRH}$, such as was observed with low levels of this neuropeptide, might serve as a termination signal for a pulse. In contrast, high levels of GnRH would be expected to summon more GnRH release to form a sustained increase. During the preovulatory GnRH surge, high sustained levels of GnRH are present and required to induce the preovulatory surge of luteinizing hormone that triggers ovulation (Sarkar et al., 1976; Moenter et al., 1991; Pau et al., 1993). Given the need for increased GnRH neuron activity during the surge, an inhibitory effect of GnRH would be counterproductive, whereas a stimulatory action of high levels of GnRH might form a positive feedback circuit among $\mathrm{GnRH}$ cells bodies to ensure sustained released of GnRH. That said, it is important to point out that the present studies were performed in males, which cannot mount a surge response. This fact, by itself, does not invalidate the above hypothesis. Both males and females generate pulsatile release and express the same GnRHR-1 signaling elements. Changes in hormonal milieu during the female cycle might also facilitate a shift from an inhibitory to a stimulatory GnRH action. For example, during positive feedback, estrogen-sensitive GPCR (G-protein-coupled receptor) peptidergic inputs to GnRH neurons may dampen $G_{\alpha \mathrm{i}}$ activity or otherwise change the ratio of activated $G$ proteins in the $\mathrm{GnRH}$ neurons, allowing stimulatory signaling systems to dominate during the surge. Of interest in this regard, increased frequency of GABAergic transmission to GnRH neurons is observed during the surge in females (Christian and Moenter, 2007), a time of high GnRH neuron activity (Christian et al., 2005) and release (Sarkar et al., 1976; Clarke and Cummins, 1982; Levine and Ramirez, 1982; Moenter et al., 1992).
A 20 nM GnRH 0
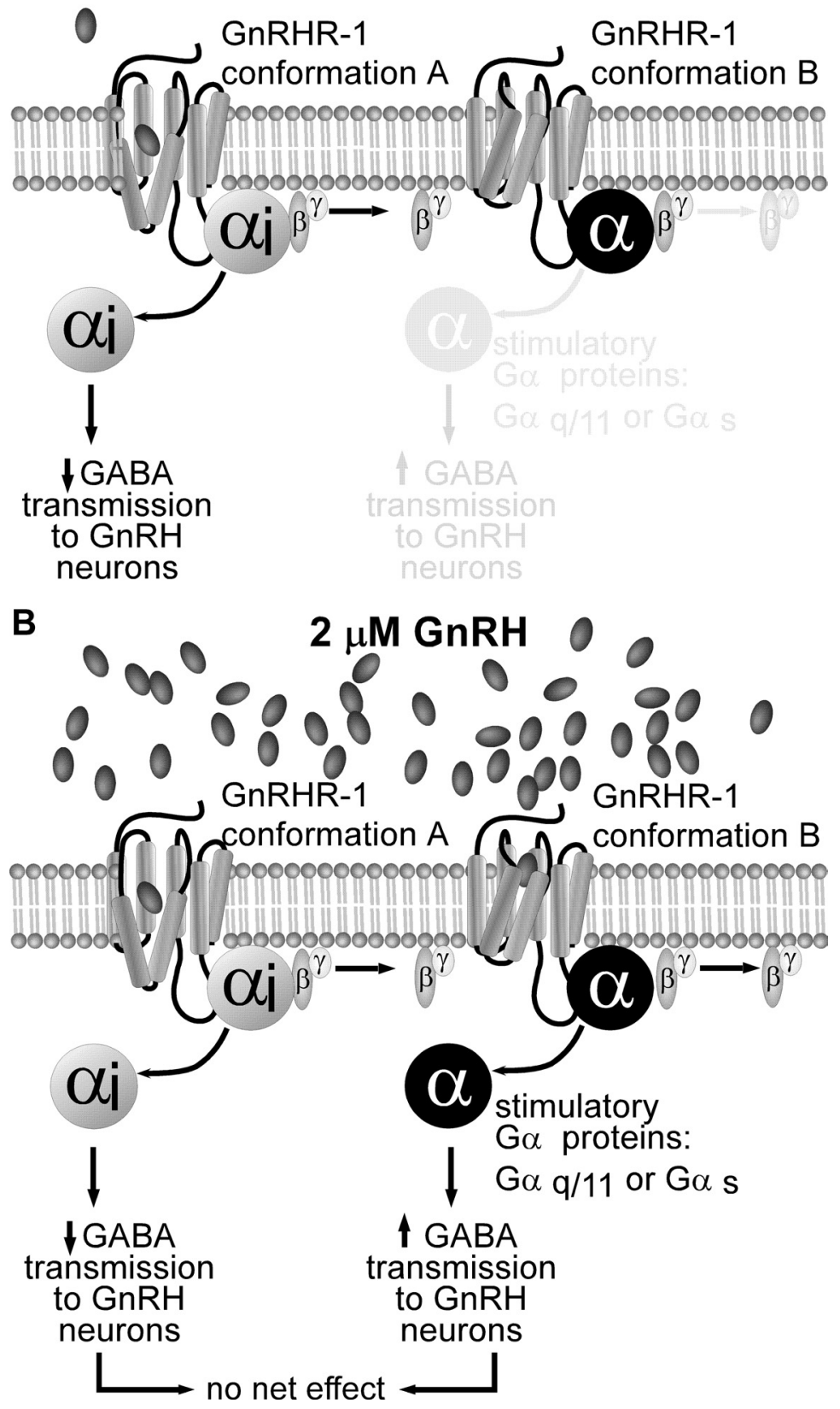

Figure 8. Schematic diagram summarizing the proposed model for concentration-dependent events that give rise to different effects in cell. There are multiple active states (conformations) of a single GnRHR-1 molecule on the cell membrane depending on being coupled to different trimeric G-protein-complexes (Millar et al., 2008). The different active receptor conformations have different binding affinity for GnRH. Depicted in this model: conformation A has higher GnRH binding affinity than conformation B. When GABA neurons are exposed to $20 \mathrm{nM} \mathrm{GnRH}(\boldsymbol{A}), \mathrm{GnRH}$ will preferentially bind and stabilize the active receptor conformation $A$ first, which will dissociate $G \alpha_{\mathrm{i}}$ from the trimeric $\mathrm{G}$-protein-complex, ultimately causing a decrease in GABAergic transmission to $\mathrm{GnRH}$ neurons. When $\mathrm{GnRH}$ is present in much higher concentration, such as depicted in $\boldsymbol{B}$, in addition to activation of conformation $A$ and its downstream effect, GnRH binds to the lower affinity conformation $B$. The active receptor conformation $B$ is coupled to stimulatory $G$ proteins (such as $G \alpha_{q / 11}$ and/or $G \alpha_{s}$ ) trimeric signaling complex. When GnRH binds and stabilizes conformation B, it will give rise to stimulatory effect within the same GABA neuron. The downstream effects of simultaneous activation of both inhibitory and excitatory signaling pathways could negate one another within the cell. This could explain the lack of effect of high concentration GnRH on GABAergic transmission under control conditions. 
The present study, in combination with previous work, provides support for the hypothesis that $\mathrm{GnRH}$ is a key mediator of GnRH neuronal activity. GnRH can inhibit or stimulate the activity of GnRH neurons directly (Todman et al., 2005; Xu et al., 2008), or via modifying its GnRHR-1-responsive GABAergic input. Evidence was also provided to support the engagement of different stimulatory and inhibitory $G$ proteins as a mechanism for concentration-dependent action of GnRH, a phenomenon previously demonstrated in cultured cell lines. How the signaling mechanisms engaged by the receptor interact with other synaptic or hormonal inputs, and how the system is influenced by stage of the female reproductive cycle, are questions for future research.

\section{References}

Bedran de Castro JC, Khorram O, McCann SM (1985) Possible negative ultra-short loop feedback of luteinizing hormone releasing hormone (LHRH) in the ovariectomized rat. Proc Soc Exp Biol Med 179:132-135.

Belchetz PE, Plant TM, Nakai Y, Keogh EJ, Knobil E (1978) Hypophysial responses to continuous and intermittent delivery of hypopthalamic gonadotropin-releasing hormone. Science 202:631-633.

Chen P, Moenter SM (2007) Gonadotropin-releasing hormone (GnRH) modifies gamma-aminobutyric acid (GABA) synaptic transmission to GnRH neurons. Soc Neurosci Abst 33:518.5/VV15.

Chen P, Moenter SM (2009) GABAergic transmission to gonadotropinreleasing hormone $(\mathrm{GnRH})$ neurons is regulated by $\mathrm{GnRH}$ in a concentration-dependent manner engaging multiple signaling pathways. Paper presented at 91st Annual Meeting Endo, Washington, DC, June.

Chen P, Li C, Haskell-Luevano C, Cone RD, Smith MS (1999) Altered expression of agouti-related protein and its colocalization with neuropeptide $\mathrm{Y}$ in the arcuate nucleus of the hypothalamus during lactation. Endocrinology 140:2645-2650.

Christian CA, Moenter SM (2007) Estradiol induces diurnal shifts in GABA transmission to gonadotropin-releasing hormone neurons to provide a neural signal for ovulation. J Neurosci 27:1913-1921.

Christian CA, Mobley JL, Moenter SM (2005) Diurnal and estradioldependent changes in gonadotropin-releasing hormone neuron firing activity. Proc Natl Acad Sci U S A 102:15682-15687.

Christian CA, Pielecka-Fortuna J, Moenter SM (2009) Estradiol suppresses glutamatergic transmission to gonadotropin-releasing hormone neurons in a model of negative feedback in mice. Biol Reprod 80:1128-1135.

Chu Z, Moenter SM (2005) Endogenous activation of metabotropic glutamate receptors modulates GABAergic transmission to gonadotropinreleasing hormone neurons and alters their firing rate: a possible local feedback circuit. J Neurosci 25:5740-5749.

Clarke IJ, Cummins JT (1982) The temporal relationship between gonadotropin releasing hormone $(\mathrm{GnRH})$ and luteinizing hormone $(\mathrm{LH})$ secretion in ovariectomized ewes. Endocrinology 111:1737-1739.

DeBock F, Kurz J, Azad SC, Parsons CG, Hapfelmeier G, Zieglgänsberger W, Rammes G (2003) Alpha2-adrenoreceptor activation inhibits LTP and LTD in the basolateral amygdala: involvement of Gi/o-protein-mediated modulation of $\mathrm{Ca} 2+$-channels and inwardly rectifying $\mathrm{K}+$-channels in LTD. Eur J Neurosci 17:1411-1424.

DeFazio RA, Heger S, Ojeda SR, Moenter SM (2002) Activation of A-type gamma-aminobutyric acid receptors excites gonadotropin-releasing hormone neurons. Mol Endocrinol 16:2872-2891.

DePaolo LV, King RA, Carrillo AJ (1987) In vivo and in vitro examination of an autoregulatory mechanism for luteinizing hormone-releasing hormone. Endocrinology 120:272-279.

Esclapez M, Tillakaratne NJ, Tobin AJ, Houser CR (1993) Comparative localization of mRNAs encoding two forms of glutamic acid decarboxylase with nonradioactive in situ hybridization methods. J Comp Neurol 331:339-362.

Fraser HM, Sellar RE, Illingworth PJ, Eidne KA (1996) GnRH receptor mRNA expression by in-situ hybridization in the primate pituitary and ovary. Mol Hum Reprod 2:117-121.

Gründker C, Völker P, Emons G (2001) Antiproliferative signaling of luteinizing hormone-releasing hormone in human endometrial and ovarian cancer cells through $\mathrm{G}$ protein alpha(I)-mediated activation of phosphotyrosine phosphatase. Endocrinology 142:2369-2380.

Han SK, Todman MG, Herbison AE (2004) Endogenous GABA release in- hibits the firing of adult gonadotropin-releasing hormone neurons. Endocrinology 145:495-499.

Hawes BE, Barnes S, Conn PM (1993) Cholera toxin and pertussis toxin provoke differential effects on luteinizing hormone release, inositol phosphate production, and gonadotropin-releasing hormone $(\mathrm{GnRH})$ receptor binding in the gonadotrope: evidence for multiple guanyl nucleotide binding proteins in GnRH action. Endocrinology 132:2124-2130.

Hsieh KP, Martin TF (1992) Thyrotropin-releasing hormone and gonadotropinreleasing hormone receptors activate phospholipase $\mathrm{C}$ by coupling to the guanosine triphosphate-binding proteins $\mathrm{Gq}$ and G11. Mol Endocrinol 6:1673-1681.

Janovick JA, Conn PM (1993) A cholera toxin-sensitive guanyl nucleotide binding protein mediates the movement of pituitary luteinizing hormone into a releasable pool: Loss of this event is associated with the onset of homologous desensitization to gonadotropin-releasing hormone. Endocrinology 132:2131-2135.

Jansen HT, Cutter C, Hardy S, Lehman MN, Goodman RL (2003) Seasonal plasticity within the gonadotropin-releasing hormone $(\mathrm{GnRH})$ system of the ewe: changes in identified GnRH inputs and glial association. Endocrinology 144:3663-3676.

Jennes L, Conn PM (1994) Gonadotropin-releasing hormone and its receptors in rat brain. Front Neuroendocrinol 15:51-77.

Kaila K (1994) Ionic basis of GABAA receptor channel function in the nervous system. Prog Neurobiol 42:489-537.

Krsmanović LZ, Stojilković SS, Mertz LM, Tomić M, Catt KJ (1993) Expression of gonadotropin-releasing hormone receptors and autocrine regulation of neuropeptide release in immortalized hypothalamic neurons. Proc Natl Acad Sci U S A 90:3908-3912.

Krsmanovic LZ, Mores N, Navarro CE, Arora KK, Catt KJ (2003) An agonist-induced switch in $\mathrm{G}$ protein coupling of the gonadotropinreleasing hormone receptor regulates pulsatile neuropeptide secretion. Proc Natl Acad Sci U S A 100:2969-2974.

Leranth C, MacLusky NJ, Sakamoto H, Shanabrough M, Naftolin F (1985) Glutamic acid decarboxylase-containing axons synapse on LHRH neurons in the rat medial preoptic area. Neuroendocrinology 40:536-539.

Levine JE, Ramirez VD (1982) Luteinizing hormone-releasing hormone release during the rat estrous cycle and after ovariectomy, as estimated with push-pull cannulae. Endocrinology 111:1439-1448.

López de Maturana R, Pawson AJ, Lu ZL, Davidson L, Maudsley S, Morgan K, Langdon SP, Millar RP (2008) Gonadotropin-releasing hormone ana$\log$ structural determinants of selectivity for inhibition of cell growth: support for the concept of ligand-induced selective signaling. Mol Endocrinol 22:1711-1722.

Martínez de la Escalera G, Choi AL, Weiner RI (1992) Generation and synchronization of gonadotropin-releasing hormone $(\mathrm{GnRH})$ pulses: intrinsic properties of the GT1-1 GnRH neuronal cell line. Proc Natl Acad Sci U S A 89:1852-1855.

Millar RP (2003) GnRH II and type II GnRH receptors. Trends Endocrinol Metab 14:35-43.

Millar RP, Pawson AJ, Morgan K, Rissman EF, Lu ZL (2008) Diversity of actions of GnRHs mediated by ligand-induced selective signaling. Front Neuroendocrinol 29:17-35.

Moenter SM, Caraty A, Locatelli A, Karsch FJ (1991) Pattern of GnRH secretion leading up to ovulation in the ewe: existence of a preovulatory GnRH surge. Endocrinology 129:1175-1182.

Moenter SM, Brand RM, Midgley AR, Karsch FJ (1992) Dynamics of gonadotropin-releasing hormone release during a pulse. Endocrinology 130:503-510.

Nunemaker CS, DeFazio RA, Moenter SM (2002) Estradiol-sensitive afferents modulate long-term episodic firing patterns of GnRH neurons. Endocrinology 143:2284-2292.

Padmanabhan V, Evans NP, Dahl GE, McFadden KL, Mauger DT, Karsch FJ (1995) Evidence for short or ultrashort loop negative feedback of gonadotropinreleasing hormone secretion. Neuroendocrinology 62:248-258.

Pau KY, Berria M, Hess DL, Spies HG (1993) Preovulatory gonadotropinreleasing hormone surge in ovarian-intact rhesus macaques. Endocrinology 133:1650-1656.

Paxinos G, Franklin BJ (2001) The mouse brain atlas: the mouse brain in stereotaxic coordinates, Ed 2. San Diego: Academic.

Pfleger KD, Pawson AJ, Millar RP (2008) Changes to gonadotropin-releasing hormone $(\mathrm{GnRH})$ receptor extracellular loops differentially affect $\mathrm{GnRH}$ an- 
alog binding and activation: evidence for distinct ligand-stabilized receptor conformations. Endocrinology 149:3118-3129.

Pielecka J, Moenter SM (2006) Effect of steroid milieu on gonadotropinreleasing hormone-1 neuron firing pattern and luteinizing hormone levels in male mice. Biol Reprod 74:931-937.

Rivera C, Voipio J, Payne JA, Ruusuvuori E, Lahtinen H, Lamsa K, Pirvola U, Saarma M, Kaila K (1999) The K+/Cl- co-transporter KCC2 renders GABA hyperpolarizing during neuronal maturation. Nature 397:251-255.

Sarkar DK, Chiappa SA, Fink G, Sherwood NM (1976) Gonadotropinreleasing hormone surge in pro-oestrous rats. Nature 264:461-463.

Silverman AJ (1994) The gonadotropin-releasing hormone (GnRH) neuronal systems: immunocytochemistry and in situ hybridization. New York: Raven.

Sim JA, Skynner MJ, Pape JR, Herbison AE (2000) Late postnatal reorganization of $\mathrm{GABA}(\mathrm{A})$ receptor signalling in native GnRH neurons. Eur J Neurosci 12:3497-3504.

Smith MS, Reinhart J (1993) ) Changes in pituitary gonadotropin-releasing hormone receptor messenger ribonucleic acid content during lactation and after pup removal. Endocrinology 133:2080-2084.

Spergel DJ, Krüth U, Hanley DF, Sprengel R, Seeburg PH (1999) GABAand glutamate-activated channels in green fluorescent protein-tagged gonadotropin-releasing hormone neurons in transgenic mice. J Neurosci 19:2037-2050.

Standish LJ, Adams LA, Vician L, Clifton DK, Steiner RA (1987) Neuroanatomical localization of cells containing gonadotropin-releasing hormone messenger ribonucleic acid in the primate brain by in situ histochemistry. Mol Endocrinol 1:371-376.

Sullivan SD, DeFazio RA, Moenter SM (2003) Metabolic regulation of fertility through presynaptic and postsynaptic signaling to gonadotropinreleasing hormone neurons. J Neurosci 23:8578-8585.

Suter KJ (2004) Control of firing by small (S)-alpha-amino-3-hydroxy-5- methyl-isoxazolepropionic acid-like inputs in hypothalamic gonadotropin releasing-hormone (GnRH) neurons. Neuroscience 128:443-450.

Suter KJ, Song WJ, Sampson TL, Wuarin JP, Saunders JT, Dudek FE, Moenter SM (2000) Genetic targeting of green fluorescent protein to gonadotropinreleasing hormone neurons: characterization of whole-cell electrophysiological properties and morphology. Endocrinology 141:412-419.

Todman MG, Han SK, Herbison AE (2005) Profiling neurotransmitter receptor expression in mouse gonadotropin-releasing hormone neurons using green fluorescent protein-promoter transgenics and microarrays. Neuroscience 132:703-712.

Valença MM, Johnston CA, Ching M, Negro-Vilar A (1987) Evidence for a negative ultrashort loop feedback mechanism operating on the luteinizing hormone-releasing hormone neuronal system. Endocrinology 121:2256-2259.

Weiss J, Cronin MJ, Thorner MO (1987) Periodic interactions of GHreleasing factor and somatostatin can augment GH release in vitro. Am J Physiol 253:E508-514.

Witkin JW, Silverman AJ (1985) Synaptology of luteinizing hormonereleasing hormone neurons in rat preoptic area. Peptides 6:263-271.

Xu C, Xu XZ, Nunemaker CS, Moenter SM (2004) Dose-dependent switch in response of gonadotropin-releasing hormone $(\mathrm{GnRH})$ neurons to GnRH mediated through the type I GnRH receptor. Endocrinology 145:728-735.

Xu C, Roepke TA, Zhang C, Rønnekleiv OK, Kelly MJ (2008) Gonadotropinreleasing hormone ( $\mathrm{GnRH}$ ) activates the m-current in $\mathrm{GnRH}$ neurons: an autoregulatory negative feedback mechanism? Endocrinology 149:2459-2466.

Yin C, Ishii H, Tanaka N, Sakuma Y, Kato M (2008) Activation of A-type gamma-amino butyric acid receptors excites gonadotrophin-releasing hormone neurones isolated from adult rats. J Neuroendocrinol 20:566-575.

Zanisi M, Messi E, Motta M, Martini L (1987) Ultrashort feedback control of luteinizing hormone-releasing hormone secretion in vitro. Endocrinology 121:2199-2204. 